College, Nottingham). Thorrowgood Scholarships have been awarded to C. R. Smith (London \& North Eastern Railway), and E. C. Norris (Southern Railway Company).

\section{Indian Cotton}

Technological Crrculars Nos. 323 to 338 issued by the Indian Central Cotton Committee's Technological Laboratory during the first three months of 1938 exemplify very thoroughly the work which is being done in India to improve the cotton crop of the country. Each season early samples of the crops from different parts of the country are sent to the Laboratory for test and each circular summarizes the results obtained in the last six years. No. 336 deals, for example, with a pure line strain isolated in 1931 and grown at the Government Experimental Farm, Akola, where the rainfall is 28 inches per annum, the soil black cotton soil, the growing period from June until November and the maximum temperature varies from $85^{\circ}$ to $115^{\circ} \mathrm{F}$.; weight of cotton per seed, 30 milligrams, of seed, $62 \mathrm{mgm}$. 26 seeds per boll, 16 to 18 bolls per plant; yield, $400-800 \mathrm{lb}$. per acre; 43 thousand acres under cultivation as against 120 acres in 1933. The average length of fibre (staple) is $\frac{7}{8}$ inch, the curve of deviation being approximately the error curve. In manufacture, the percentage of loss from dirt is low, that from carding is normal, about 8 per cent. Fibre strength was best in 1933 and then suitable for yarn of 31 counts, that is, 31 hanks of 480 yards to the pound.

\section{Butterfly Migrations in the Tropics}

THE attention of travellers and residents in the tropics is directed to an attractively produced booklet entitled "Butterfly Migrations in the Tropics", recently published by the British Museum (Natural History). It is written on behalf of the Trustees of the Museum by Dr. C. B. Williams, and is well illustrated by means of five three-colour process plates of typical migrant species. The booklet is issued primarily with the object of obtaining information on the subject of migration. Very little is known relative to this problem in the tropics, and it is easy for any accurate and willing observer to assist in this matter. Instructions are given with regard to the special points upon which information is desired. The booklet may be obtained from the British Museum (Natural History), London, S.W.7, price $9 d$.

\section{International Grassland Congress}

THE report of the fourth International Grassland Congress held in Great Britain in July 1937 under the presidency of Prof. R. G. Stapledon has now been published. The volume, which consists of 486 pages, contains the full texts of all papers, both plenary and sectional, delivered to the Congress at Aberystwyth. Each is printed in English or German with a summary in the alternative language, the main items of the discussion being also included. The report can be obtained from the Joint Secretaries, Fourth International Grassland Congress, Aberyst- wyth, for £2, post paid. A smaller volume (pp. 87), containing abstracts in English and German of the majority of the papers delivered, is available for 58 . post paid.

\section{Work of the Central Midwives Board}

The report of the Central Midwives Board, recently issued, reviews the work of the Board during the year ended March 31, 1937. The Midwives Roll contained the names of 65,046 women, a net increase of 2,982 on last year's roll. During the year, only 18 midwives were dealt with by the Board under its penal powers on charges of malpraxis, negligence or misconduct, as a result of which seven names were removed from the roll. The Minister of Health approved the revised rules for training and examination, on the preparation of which the Board has been engaged for a considerable time. The two most important changes effected by the new rules are (a) an extension of the period of training from 6 to 12 months for State-registered general trained nurses, and from 12 to 24 months for other pupilmidwives, and $(b)$ division of the course of training into two parts, each of which will be completed by an appropriate examination. An important decision during the year was the permission given to midwives to administer nitrous oxide and air to women in childbirth, under certain conditions.

\section{Congress of Electroradiology}

THE fourth annual Congress of French-speaking Electro-Radiologists will be held in Paris on October 5-8. At the opening meeting, Prof. Joliot-Curie will lecture on neutrons and artificial radio-elementsbiological applications and therapeutical hypotheses. The following subjects will also be discussed: the results of radiological methods of examination; the bio-electric phenomena of the nervous system, present state of the question and possible application; anti-inflammatory roentgentherapy; biological action of rays and high-frequency currents; progress of histo-radiography; fresh data on neuro-muscular stimulation; interpretation of electrotoric phenomena. The subscription is 100 francs, which should be sent to Dr. Morel Kahn, 45 rue Scheffer, Paris $16^{\mathrm{e}}$. Further information can be obtained from Dr. Delherm, 1 rue Loas Cases, Paris $7^{e}$.

\section{Studentships and Fellowships in Medical Research}

THE Medical Research Council invites applications for a third series of studentships and fellowships intended to encourage young British medical graduates towards becoming investigators in those branches of medical science which are concerned directly with disease as it occurs in human beings. Post-graduate studentships are offered for medical graduates who have already held house appointments and are strongly inclined to a career in clinical science or experimental pathology. Each selected student will receive a stipend at the rate of $£ 200$ per annum, during a period not exceeding twelve months, for personal maintenance while undertaking approved courses of study in Great Britain such as may be 